\title{
Chapter 13 \\ Flash Flood Modeling and Mitigation in Arid and Semiarid Basins: Case Studies from Oman and Brazil
}

\author{
Mohamed Saber, Sameh A. Kantoush, Mohammed Abdel-Fattah, \\ Tetsuya Sumi, Jose Andres Moya, and Karim Abdrabo
}

\begin{abstract}
The behaviors and impacts of flash floods (FF) are different based on the climatic regions. To understand such difference, two case studies were selected for the analysis: Wadi Uday, Oman and Sume Basin, Paraiba, Brazil. The rainfall-runoff inundation model (RRI) was used to simulate the discharge and flood inundation of the recent flood events to understand the severity and frequency of flash floods to better assess the current mitigation measures. The current FF situations in arid and semiarid basins were analyzed, and the hazards associated with flood phenomenon were assessed for various calculated rainfall return periods using RRI model. To this end, a flash flood index (average water depth per total basin area) was calculated as a basis to understand the impact of flash floods. A coupling of this index with the FF histories was included to provide a comprehensive overview of the FF vulnerability of arid and semiarid basins. We concluded that
\end{abstract}

M. Saber $(\bowtie) \cdot$ S. A. Kantoush · T. Sumi

Disaster Prevention Research Institute (DPRI), Kyoto University, Kyoto 611-0011, Japan

e-mail: mohamedmd.saber.3u@kyoto-u.ac.jp

S. A. Kantoush

e-mail: kantoush.samehahmed.2n@kyoto-u.ac.jp

T. Sumi

e-mail: sumi.tetsuya.2s@kyoto-u.ac.jp

M. Abdel-Fattah

Civil Engineering and Quantity Surveying Department, Military Technological College, P.O.

Box: 262, Muscat 111, Oman

e-mail: Mohammed.Soliman@mtc.edu.om

K. Abdrabo

Faculty of Urban and Regional Planning, Cairo University, Giza 12613, Egypt

e-mail: m.karim.ibrahim@cu.edu.eg

J. A. Moya $\cdot$ K. Abdrabo

Department of Urban Management, Graduate School of Engineering, Kyoto University,

Kyoto 615-8245, Japan

(C) The Author(s) 2022

T. Sumi et al. (eds.), Wadi Flash Floods, Natural Disaster Science and Mitigation

Engineering: DPRI Reports, https://doi.org/10.1007/978-981-16-2904-4_13 
FFs tend to be more severe and extreme in arid regions than in semiarid regions, despite the lower frequency of FFs and the water scarcity in arid regions. Distributed dams also proved to be more effective in preventing FFs in arid regions than in semiarid regions.

Keywords Wadi flash flood - Arid and semiarid basins - Mitigation measures • Hydrological modeling • Flood index - Concentrated and distributed dams •

Oman · Brazil

\subsection{Introduction}

However, arid and semiarid areas make up approximately one-third of the total area of the world, and there are implications caused by the expansion of urban regions due to the increase in population (Huang et al. 2016; Metzger et al. 2020) that consequently lead to intensified flash flood risks. Despite this, previous studies addressing flash floods in these regions are still limited. A spatiotemporal analysis of rainfall variability over the Middle East and North Africa (MENA) region showed high spatiotemporal variability over the region in terms of the frequency and intensity of flash flood events (Saber et al. 2017, 2020). Additionally, the maximum rainfall in storms and the number of extreme rainfall events will increase in the future (Tanaka* et al. 2020), leading to higher risks of wadi-related flash floods in such regions.

The lack of high-quality data on wadi flash flood events in both arid and semiarid regions hinders efforts to mitigate flooding risks (Abdrabo et al. 2020; Chimnonyerem n.d.; Wheater et al. 2007; Rogger et al. 2014; Saber and Habib 2016; Abdel-Fattah et al. 2017; Saber et al. 2010). Most previous studies have mainly focused on arid or semiarid case studies separately; however, a few previous studies have focused on both regions. Therefore, understanding the difference between arid and semiarid regions as well as assessing the flash flood risks using distributed hydrological models is crucial for better flood risk reduction and proposing proper mitigation measures in such regions.

Flash flood hazards and risk assessments have been discussed in some previous studies in arid and semiarid regions, and these studies have addressed the impact of extreme rainfall variability in urban regions (Pathirana et al. 2014; Saber et al. 2020). However, the optimal methods for managing flood hazards in both regions are not very clear. The challenges of applying the concept of flood-risk management in practice might be attributed to the lack of proper planning approaches that take the flood issues into account or the lack these approaches being used in practice. The uncertainty of using floodplain mapping to efficiently capture the likelihoods of losses of property and human lives has caused real problems for local communities. In many cases, structural mitigation measures in arid and semiarid regions are not always optimum solutions. The core problem, as summarized in a World Bank report (Jha et al. 2012), is that poorly designed and managed urbanization 
contributes to the growing flood risk due to unsuitable land-use changes. Urban expansion often occurs in a pattern of unplanned development in flood-prone regions (Huang and Shen 2019; Abdel-Fattah et al. 2017).

Flash floods have been highlighted in the twenty-first century for the damage they have caused, particularly in the more arid regions of the world, as climate change intensifies. In northern Brazil, for instance, which is the most populated semiarid region in the world (Cutter et al. 2013) at 30 million people, a sizeable portion of the population lives at risk due to flash floods (Alcantara et al. 2013). Families often must walk several kilometers every day to obtain water, which increases their vulnerability (Lindoso et al. 2018; Lindoso and Filho n.d.). On the other hand, Oman has experienced major flash floods, such as the Gonu Cyclone in 2007, which caused 4 billion USD worth of infrastructure damage and 49 deaths (Wang and Zhao 2008). It was stated that urbanization in Wadi Uday within this time period (1960-2003) was dramatically increasing (Al-Rawas 2011, 2013). Such urbanization expansions contribute directly to increasing the disastrous impacts of flash floods. In addition, there is a lack of substantial research focusing on flash flood disaster impacts and mitigation measures in both arid and semiarid basins. In the Sume Basin in the State of Paraiba, Brazil, the areas of corn and bean plantations, which account for the economic sustainability of many residents, have also increased in recent history. In addition, water has become increasingly scarce, which has placed increased importance on dams and flood mitigation measures. In light of this, the government has set up websites that make real-time measurements of the fullness of reservoirs.

The main objective of this study is to holistically compare arid and semiarid basins, considering characteristics such as the climate, aridity, hydrology, etc., of the two types of basins in addition to understanding flash flood phenomena in selected basins in Oman and Brazil. With this framework, a hydrological rainfall-runoff model was applied to assess the flood hazard levels based on calculations of the flood index (average water inundation depth per basin area). Abdel-Fattah et al. (2021) studied flash floods in wadi systems considering different scenarios of mitigation measures, stating that both distributed and single dam structures each have some advantages and disadvantages depending on the purposes and objectives of the proposed dams. Therefore, this study also compared the efficiency of different mitigation measures for flash floods, considering both concentrated and distributed dam scenarios to evaluate which scenario is more advantageous for the region from a comprehensive perspective.

\subsection{Comparison Between Arid and Semiarid Basins}

Approximately one-third of the land in the world is deemed to be arid or semiarid according to the Food and Agriculture Organization (FAO) of the United Nations. Both climate types are characterized by severe drought and rare precipitation (Lin 1999) and are generally vulnerable to flash floods. The two regions were compared 
Table 13.1 General comparison between arid and semiarid areas

\begin{tabular}{|c|c|c|c|}
\hline Type & \multicolumn{2}{|l|}{ Semiarid } & Arid \\
\hline Temperature $\left({ }^{\circ} \mathrm{C}\right)$ & \multicolumn{2}{|l|}{$23-27$} & $45-48$ \\
\hline $\begin{array}{l}\text { Annual average } \\
\text { rainfall }(\mathrm{mm})\end{array}$ & \multicolumn{2}{|l|}{$200-400$} & $<200$ \\
\hline Evaporation (mm) & \multicolumn{2}{|l|}{2,000} & $2,500-3,000$ \\
\hline Aridity index (AI) & \multicolumn{2}{|l|}{$0.2<\mathrm{AI}<0.5$} & $\mathrm{AI}<0.2$ \\
\hline Global land area & \multicolumn{2}{|l|}{$17.70 \%$} & $12.10 \%$ \\
\hline $\begin{array}{l}\text { Annual runoff depth } \\
(\mathrm{mm})\end{array}$ & \multicolumn{2}{|l|}{$10-50$} & $<10$ \\
\hline Mitigation measures & $\begin{array}{l}\text { Flood protection } \\
\text { dams }\end{array}$ & \begin{tabular}{|l} 
recharge \\
dams
\end{tabular} & $\begin{array}{l}\text { Storage dams, groundwater } \\
\text { recharge dams }\end{array}$ \\
\hline Infiltration & \multicolumn{2}{|l|}{$>$ Arid regions } & $<$ Semiarid regions \\
\hline Drainage density & \multicolumn{2}{|l|}{$<4 \mathrm{~km} / \mathrm{km}^{2}$} & $10 \mathrm{~km} / \mathrm{km}^{2}$ \\
\hline Vegetation cover & \multicolumn{2}{|l|}{$>$ Arid regions } & $<$ Semiarid regions \\
\hline
\end{tabular}

Source (Data source): Moya et al. (2017)

and summarized as shown in Table 13.1. Arid and semiarid basins were compared in terms of hydrology, climatology, precipitation, and geomorphology. This comparison covered many aspects as follows: temperature, annual average rainfall, evaporation, the aridity index, global land area, annual runoff depth, mitigation measures, infiltration rate, drainage density and vegetation cover. There is a long-standing perception that intense rainfall-runoff events are more common in semiarid regions than in arid regions despite a lack of documentation. Arid and semiarid areas typically lack the vegetation cover, mature soil profiles, and humus layers that generally intercept and store precipitation, enhance infiltration and attenuate storm runoff in areas with moist climates. Compared with semiarid climates, sparsely vegetated soils in arid areas are commonly thin or absent and exhibit low rates of infiltration of rainfall due to soil-particle compaction by raindrop impacts (Anon 2000). Drainage density factor values in arid climates are typically regarded as low $\left(<4 \mathrm{~km} / \mathrm{km}^{2}\right)$, while those in semiarid regions average approximately $10 \mathrm{~km} / \mathrm{km}^{2}$, indicative of the maximum event runoff, short distances to drainage ways, and high potentials for high-magnitude discharge event (Knighton 1984).

\subsubsection{Climate Conditions}

Both arid and semiarid basins are affected by drought and very infrequent rainfall coupled with high temperatures (Lin 1999). Records indeed show the existence of prolonged drought periods that can extend for several years in some cases, as evidenced in. Oman is no exception, with potential evaporation that ranges from 2,000 to $3,000 \mathrm{~mm}$ and temperature varying from $3{ }^{\circ} \mathrm{C}$ in the mountains in winter 
to temperatures exceeding $45^{\circ} \mathrm{C}$ and reaching up to $48{ }^{\circ} \mathrm{C}$ in summer. In Brazil, annual average temperatures usually range from 24 to $26^{\circ} \mathrm{C}$, and temperatures exceed this range in places where the altitude is below 200 or, in some cases, $300 \mathrm{~m}$ (Malveira et al. 2012). However, climate change is making temperatures higher; in the last 41 years, maximum temperatures in the Northeastern Region of Brazil have increased from 1.5 to $2{ }^{\circ} \mathrm{C}$ (F. Lacerda Meteorology-ITEP). For the Sume Basin, average annual temperatures vary from 23 to $27{ }^{\circ} \mathrm{C}$, with daily temperatures having a $10{ }^{\circ} \mathrm{C}$ range of variance (Alcantara et al. 2013). The aridity index was calculated for each basin according to UNEP by the following formula:

$$
A I=\frac{P}{\mathrm{PET}}
$$

where $P$ stands for the average annual precipitation and PET is the potential evapotranspiration. The $A I$ was calculated to be 0.036 for the Wadi Uday basin and 0.25 for the Sume Basin.

\subsubsection{Precipitation}

Precipitation in arid and semiarid areas tends to present high variance (Geber et al. 2008) and randomness factors. In Wadi Uday, the rainy season occurs from November to April in winter and is often caused by thunderstorms, while the dry season occurs in summer from May to October, during which large rainfall events still sparsely occur (Ministry of Regional Municipalities and Water Resources 2009). According to the Ministry of Regional Municipalities and Water Resources, the annual average rainfall measured from 1995 to 2008 was $90 \mathrm{~mm}$. Oman has been the subject of many tropical cyclones that often develop in the Arabian Sea, causing heavy rain and floods (Saleh and Al-Hatrushi n.d.), as evidenced in Fig. 13.1. Records also show the existence of prolonged drought periods, as exemplified in, which can extend for several years in some cases. Rainfall variability is very high in Oman, with the average yearly rainfall ranging from $76.9 \mathrm{~mm}$ in the interior of the country to a high of $181.9 \mathrm{~mm}$ in the Dhofar Mountains, according to data collected from 1997 to 2003 (Kwarteng et al. 2009).

The average annual rainfall in the Sume Basin tends to vary from 550 to $600 \mathrm{~mm}$ based on the last 50 years of measurements. The semiarid climate in this basin is characterized by irregular rainfall and a clear divide between two seasons: the dry season, which ranges from June until January, and the rainy season, which extends from February until May. The region is well-known for its remarkable rainfall intensity variability associated with the low total annual rainfall values that characterize much of the Northeastern Region of Brazil (Silva et al. 2007). Especially due to the Intertropical Convergence Zone (ITCZ), there is high rainfall variability in this region; along the coast, the annual average rainfall surpasses 


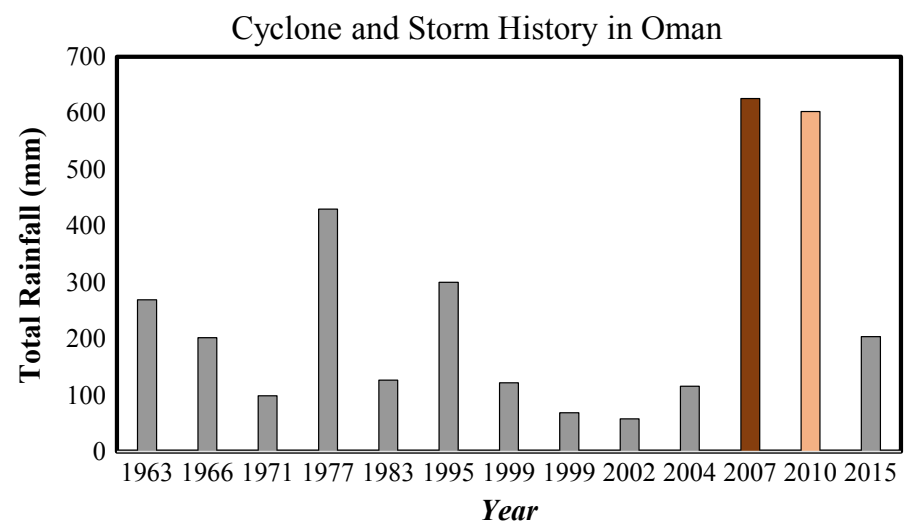

Fig. 13.1 List of cyclones in Oman from 1963 until 2015; 2007 and 2010, highlighted, stand for the Gonu and Phet cyclones, respectively. Source data Al Barwani, A., 2015. Flash flood mitigation and harvesting Oman case study, first international symposium on flash floods (ISFF). DPRI, Kyoto University, Kyoto, Japan

$1,000 \mathrm{~mm}$, while toward the backland, the average hovers at approximately $500 \mathrm{~mm}$ (Silva et al. 2007).

The PERSSIAN CDR data (Ashouri et al. 2015) from 1983 to 2019 were analyzed for both countries, and we found that the annual trend of rainfall in Brazil is decreasing, but in Oman, it is slightly increasing. The maximum annual average rainfall over Oman is limited to less than $200 \mathrm{~mm} / \mathrm{year}$, but in Brazil, it is over 2,000 mm/year (Figs. 13.2 and 13.3).

\subsubsection{Flash Floods in Arid and Semiarid Basins}

Flash floods are defined as floods that rapidly develop within a very small amount of time, usually a few minutes or hours, due to excessive rainfall (Abdel-Fattah et al. 2015). There are many types of floods that are very destructive with different features and characteristics, such as coastal flooding of land areas around coasts due to high tides and/or heavy rainfall; river flooding where the water level surpasses the top of a riverbank due to excessive rainfall; urban/pluvial flooding, which occurs in urban areas due to heavy rainfall, exceeding the capacity of the drainage systems; and reservoir flooding, which occurs as a result of dam failures. Additionally, wadi-related flash floods occur in catchments, urban areas or both due to extreme rainfall events in most cases. With climate change in recent years, flash floods have intensified; in Oman, for instance, major flash floods occurred in 1989, 1997, 2002, 2003, 2007, 2010, 2015 and 2016, as shown in Table 13.2. There are some other common characteristics of flash floods in arid and semiarid areas, such as the difficulty of forecasting flash floods due to the suddenness of flash flood 

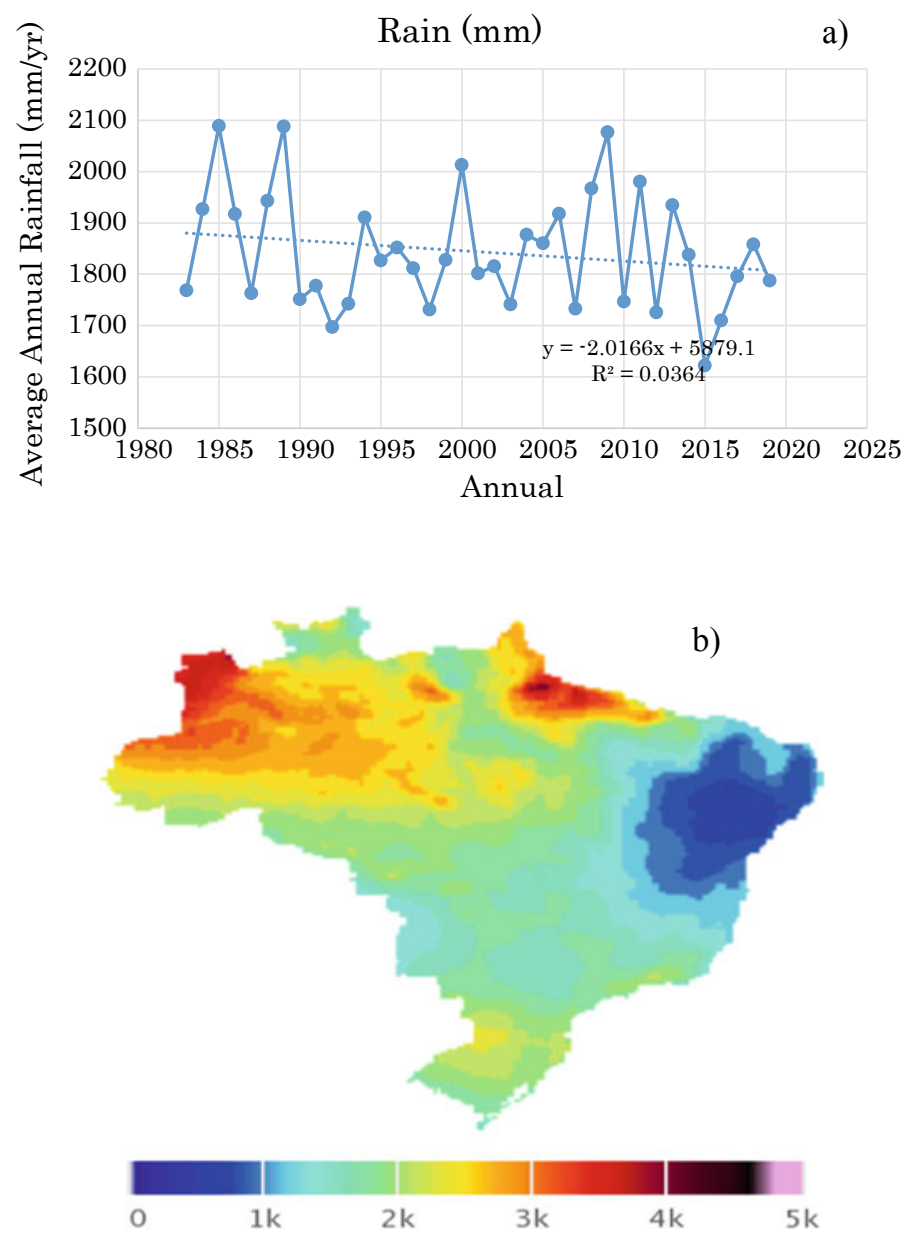

Fig. 13.2 Annual average precipitation from PERSSIAN-climatology data over Brazil: a time series annual average, b total average from 1983 to 2019. Source data Ashouri et al. (2015). For citation "PERSIANN-CDR: daily precipitation climate data record from multisatellite observations for hydrological and climate studies." Bulletin of the American Meteorological Society 96.1 (2015): 69-83

occurrences, the scarcity of data, and the area distribution being statistically random (Lin 1999). In Brazil, many flash floods are caused by the breakage or spilling of dams or levies. Flash floods can also carry downed trees, boulders, and debris along wadi beds to alluvial fans, as is often seen in many wadis, such as Wadi Uday and Wadi Samail (Al-Rawas 2013). 


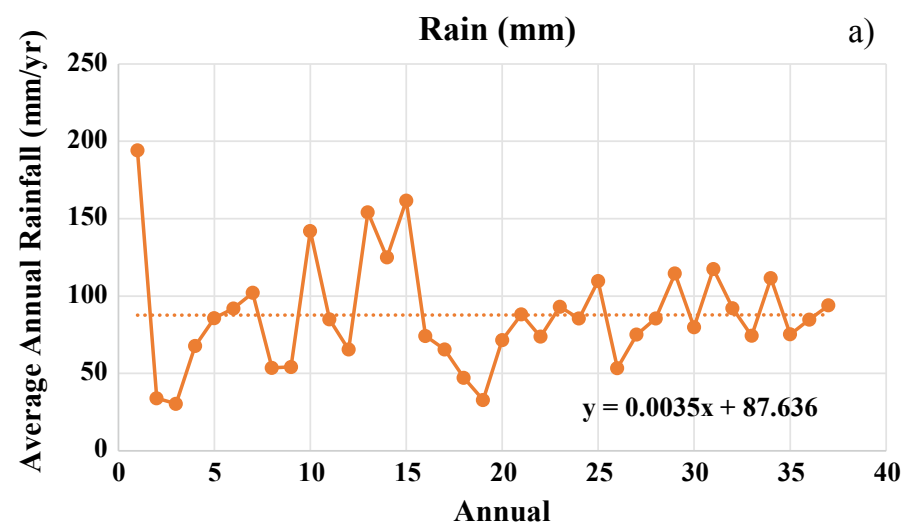

b)

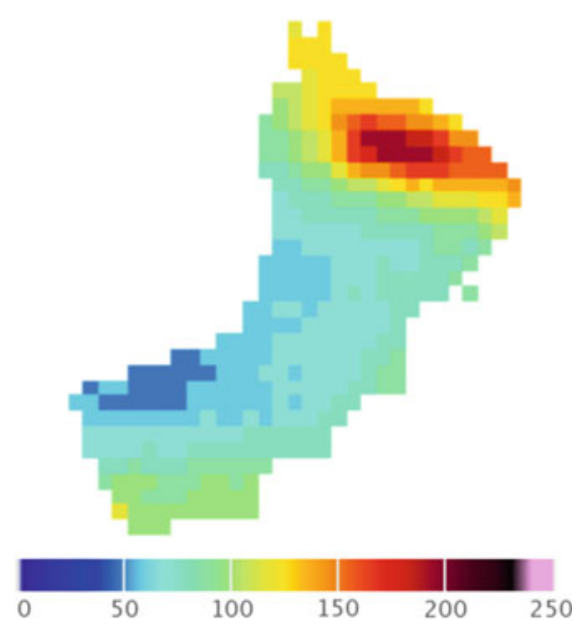

Fig. 13.3 Annual average precipitation from PERSSIAN-climatology data over Oman: an annual average time series, b total average from 1983 to 2019. Source data Ashouri et al. (2015)

\subsubsection{Current Mitigation Measures in Arid and Semiarid Basins}

Mitigation measures for flash floods have played an increasingly pivotal role in recent years, with the intensification of flash floods coupled with urban expansion into flood-risk areas (Abdel-Fattah et al. 2021; Al-Rawas 2013). Partially stemming from this, the Omani government created a seven-dam project in the Wadi Uday basin. This study considered the similar conditions of the seven dams, as shown in Fig. 13.4 and Table 13.3. 
Table 13.2 History of flash floods in Oman

\begin{tabular}{|c|c|c|c|c|c|c|c|}
\hline Year & Location & Began & Ended & $\begin{array}{l}\text { Duration } \\
\text { (days) }\end{array}$ & Missing & Displaced & $\begin{array}{l}\text { Area } \\
\left(\mathrm{km}^{2}\right)\end{array}$ \\
\hline 1989 & Muscat & $\begin{array}{l}14 \\
\text { Sept }\end{array}$ & $\begin{array}{l}16 \\
\text { Sept }\end{array}$ & 3 & 2 & NA & 72,160 \\
\hline 1997 & Dibba & \begin{tabular}{|l|}
21 \\
June
\end{tabular} & $\begin{array}{l}23 \\
\text { June }\end{array}$ & 3 & 4 & NA & 21,980 \\
\hline 2002 & Salalah & \begin{tabular}{|l}
10 \\
May
\end{tabular} & $\begin{array}{l}12 \\
\text { May }\end{array}$ & 3 & 9 & 100 & 9,460 \\
\hline 2003 & $\begin{array}{l}\text { Nizwa Muscat/ } \\
\text { Muscat, Dhofar }\end{array}$ & \begin{tabular}{|l}
14 \\
April \\
\end{tabular} & $\begin{array}{l}19 \\
\text { April }\end{array}$ & 6 & 30 & NA & 23,060 \\
\hline 2005 & $\begin{array}{l}\text { Batinah Nizwa } \\
\text { Musandam }\end{array}$ & $\begin{array}{l}01 \\
\text { March }\end{array}$ & $\begin{array}{l}23 \\
\text { March }\end{array}$ & 23 & 7 & 700 & 489,000 \\
\hline 2007 & Muscat & $\begin{array}{l}06 \\
\text { July }\end{array}$ & $\begin{array}{l}12 \\
\text { July }\end{array}$ & 7 & 61 & 60,000 & 373,000 \\
\hline 2010 & Muscat & $\begin{array}{l}\text { May } \\
31\end{array}$ & June 6 & 7 & 24 & NA & 150,000 \\
\hline 2015 & $\begin{array}{l}\text { Masirah Island/ } \\
\text { Muscat }\end{array}$ & 8 June & $\begin{array}{l}12 \\
\text { June }\end{array}$ & 5 & 105 & 50,000 & 50,000 \\
\hline
\end{tabular}

Source Moya (2017)

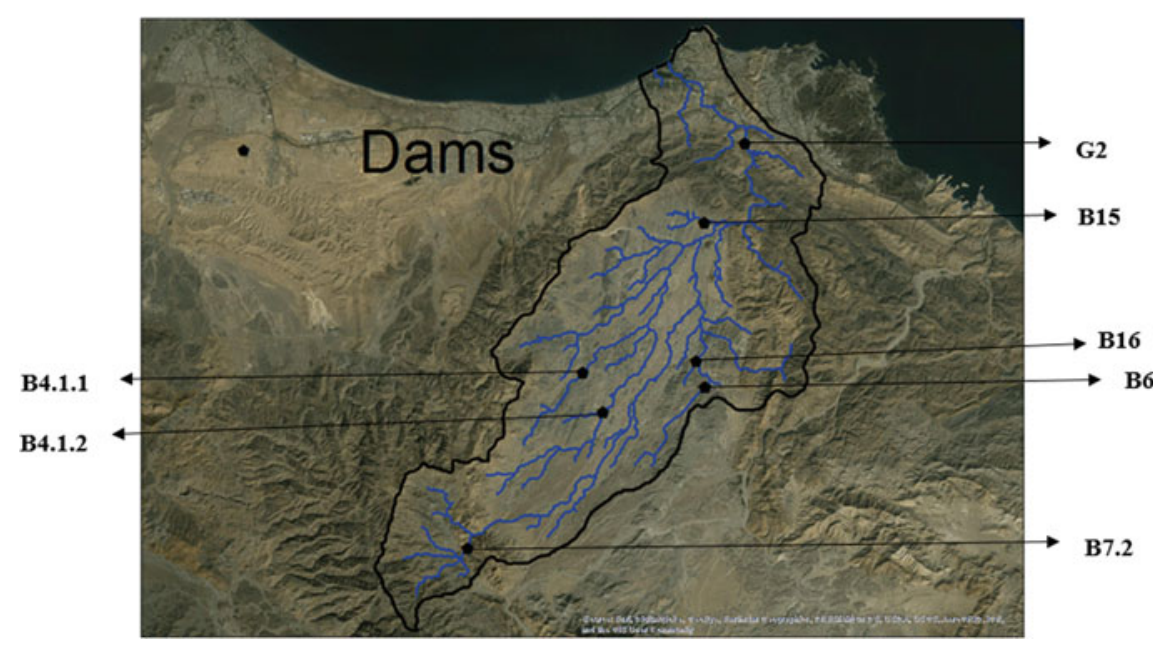

Fig. 13.4 Dam locations in the Wadi Uday basin. Source Moya (2017)

Flash flood measures in arid and semiarid areas can mainly be divided into 2 categories: structural and nonstructural measures, as shown in Table 13.4. According to the Ministry of Regional Municipalities and Water Resources (MRMWR), the established dams in Oman are not limited to flood protection dams but also include groundwater recharge and storage dams. In Wadi Uday basin, for 
Table 13.3 List of dams and their characteristics in the Wadi Uday basin

\begin{tabular}{l|l|l|l|l|l}
\hline $\begin{array}{l}\text { Dam } \\
\text { ID }\end{array}$ & Dam name & $\begin{array}{l}\text { Dam } \\
\text { height }(\mathrm{m})\end{array}$ & $\begin{array}{l}\text { Dam } \\
\text { coordinates }\end{array}$ & Dam type & $\begin{array}{l}\text { Reservoir storage } \\
\text { volume }\left(10^{6} \mathrm{~m}^{3}\right)\end{array}$ \\
\hline B15 & $\begin{array}{l}\text { Al Amerat } \\
\text { Heights }\end{array}$ & 22 & $\begin{array}{l}\text { Lat: } 23.54^{\circ} \\
\text { Long: } \\
58.49^{\circ}\end{array}$ & Embankment & 22 \\
\hline G2 & $\begin{array}{l}\text { Wadi Uday } \\
\text { Gorge }\end{array}$ & 45 & $\begin{array}{l}\text { Lat: } 23.58^{\circ} \\
\text { Long: } \\
58.52^{\circ}\end{array}$ & Embankment & 26 \\
\hline B6 & Al Jufainah & 28 & $\begin{array}{l}\text { Lat: } 58.5^{\circ} \\
\text { Long: } \\
23.45^{\circ}\end{array}$ & Embankment & 16 \\
\hline B7.2 & Al Humaniyah & 58 & $\begin{array}{l}\text { Lat: } 23.36^{\circ} \\
\text { Long: } \\
58.36^{\circ}\end{array}$ & Concrete & 8.6 \\
\hline B4.1.2 & $\begin{array}{l}\text { Madinat Al } \\
\text { Nahdah S }\end{array}$ & 20 & $\begin{array}{l}\text { Lat: } 23.46^{\circ} \\
\text { Long: } \\
58.42^{\circ}\end{array}$ & Embankment & 4 \\
\hline B16 & Al Mahag & 18 & $\begin{array}{l}\text { Lat: } 23.44^{\circ} \\
\text { Long: } \\
58.43^{\circ}\end{array}$ & Embankment & 6 \\
\hline Long: $58.5^{\circ}$ & Embankment & 5 \\
\hline
\end{tabular}

Source data Ministry of Regional Municipalities and Water Resources, Oman

instance, after the destruction caused by the Gonu Cyclone, 16 dams were examined for a project to build 7 flood protection dams (currently, only one has been built). In Brazil's case, the main mitigation measures mainly consist of flood-risk maps and evacuation measures as well as storage reservoirs of various sizes (Malveira et al. 2012). Although there are tens of thousands of storage dams in the Northeastern Region of Brazil, only some of these storage dams have flood mitigation functions.

Table 13.4 Structural and nonstructural measures for flash flood mitigation

\begin{tabular}{l|l}
\hline Structural & Nonstructural \\
\hline $\begin{array}{l}\text { Improve channel drainage efficiency by } \\
\text { increasing channel width and depth }\end{array}$ & $\begin{array}{l}\text { Monitor and forecast water situations and } \\
\text { rainfall in the target basin }\end{array}$ \\
\hline Flood protection dams & Accelerate drainage of water in low-lying areas \\
\hline Flood walls and levees & $\begin{array}{l}\text { Reduction of flood peaks that pass close to } \\
\text { communities by diverting upstream water }\end{array}$ \\
\hline Floodways & Land-use zoning and flood-risk maps \\
\hline Embankments & Floodplain management \\
\hline
\end{tabular}

Source Moya (2017) 


\subsection{Study Areas}

\subsubsection{Semiarid Region: Sume Basin, Brazil}

The Sume Basin is located in the Northeastern Region of Brazil, as shown in Fig. 13.5, which has an area of 1.6 million $\mathrm{km}^{2} ; 86 \%$ of this area is deemed to be semiarid (Marengo et al. 2008). This region is often referred to as the drought polygon due to its particular fragility and poor level of development, which is exacerbated by the frequent droughts that occur in the area. The Northeastern Region of Brazil is formed by nine states, and the Sume Basin is located in the state of Paraiba, as shown in Fig. 13.5. The basin itself has an area of approximately $128 \mathrm{~km}^{2}$, and according to a 2014 IBGE report (Brazilian Institute of Geography and Statistics), the population contained in this basin is 51,000. The hydrographic basin constituting the Sume Basin is located between the municipalities of Sume and Monteiro, bounded by the coordinates of $7^{\circ} 40^{\prime}$ south latitude and $37^{\circ} 0^{\prime}$ east longitude (Cadier and Jose de Freitas 1982). The Sume Basin is divided into three subbasins: Jatoba, Umburana and Gangorra.

To run the RRI model, daily rainfall data from the Superintendence for the Development of the Northeast (SUDENE) were used for the 1985 floods, which had huge impacts in the majority of the Northeastern Region of Brazil. Rainfall return
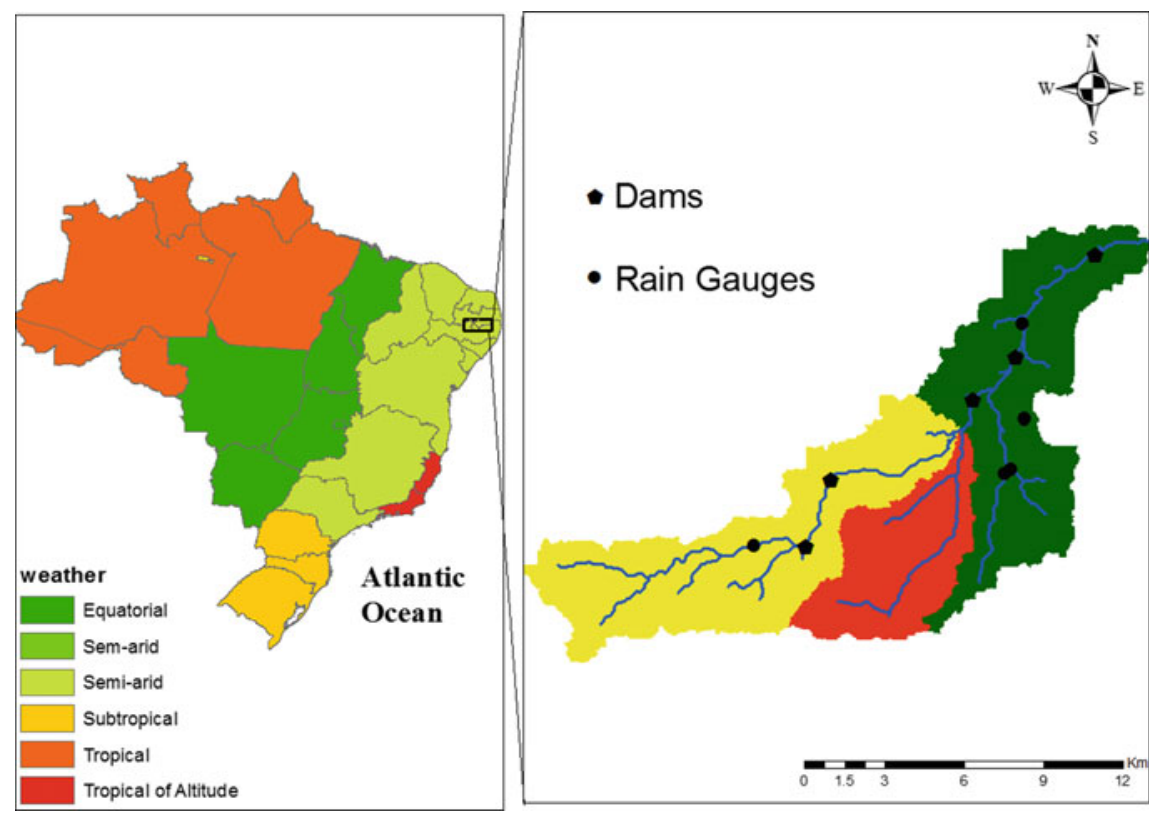

Fig. 13.5 Map of the Sume Basin in Paraiba, Brazil, showing the locations of dams and rain gauges. Reprinted (modified) from Moya et al. (2017) 
periods were also calculated using rainfall data from SUDENE. GSMaP data were also used to simulate the floods that occurred in 2014 in Sume. This simulation was run using the rainfall intensity values calculated from the 1985 floods and a 100 -year rainfall return period. For topographic data, a 30-s resolution, which is equivalent to approximately $1 \mathrm{~km}$ per cell, was used from the HydroSHEDS data.

\subsubsection{Wadi Uday Basin}

The Wadi Uday basin is located in the Muscat governorate of Oman, which is the fastest-growing part of the country (Al-Rawas 2013), with a population of $1,288,300$ according to a 2015 census made by the National Centre for Statistics and Information. The basin itself has an area of $372 \mathrm{~km}^{2}$, with a total urbanized area of approximately $85 \mathrm{~km}^{2}$, which represents approximately $22 \%$ of the total watershed area. Wadi Uday is bounded by the coordinates $23^{\circ} 40^{\prime}$ north latitude and $58^{\circ} 35^{\prime}$ east longitude. Figure 13.6a shows the watershed delineation and its geographical location in the Middle East, as well as the rain gauges that were used to collect rainfall measurements in the basin. The basin is also almost entirely surrounded by mountains, which greatly increases the risk of flash floods.

The Gonu Cyclone in June 2007 was the event chosen for the calibration, using data from the MRMWR measured from the rain gauges shown in Fig. 13.6b. For the model validation, a major flood event that occurred in December 2006 was chosen, and the same sources of data were used. The main geologic base of the soil in this basin is made up of basaltic, limestone and sandstone rock according to data from the MRMWR.

\subsection{Data Processing and Methods}

First, the available rainfall and discharge data were collected. Data collected from 1983 to 2015 by 6 rain gauges were used for Wadi Uday in Oman, and data collected from 1982 until 1991 were taken from 5 rain gauges for Sume Basin in Brazil. In addition to satellite-based rainfall data, GSMaP data were also used in Oman to simulate the 2007 Gonu Cyclone and the March 1985 large floods in Brazil. 


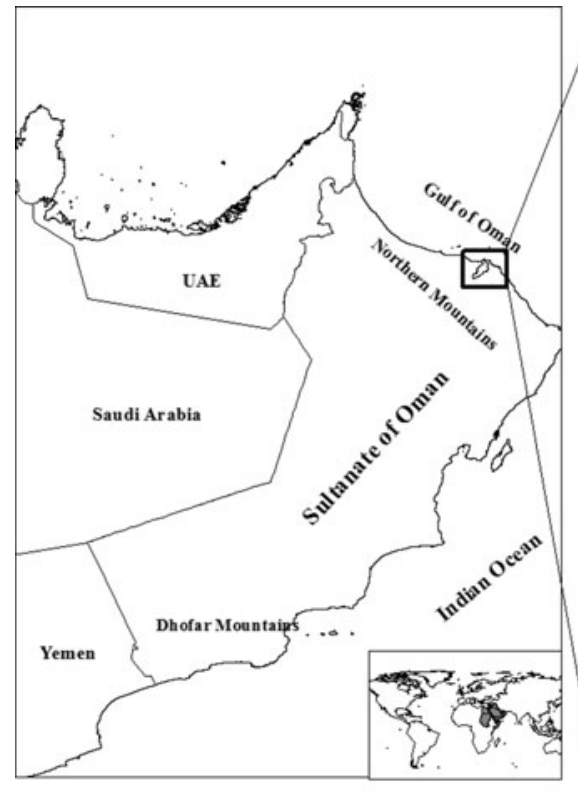

a)

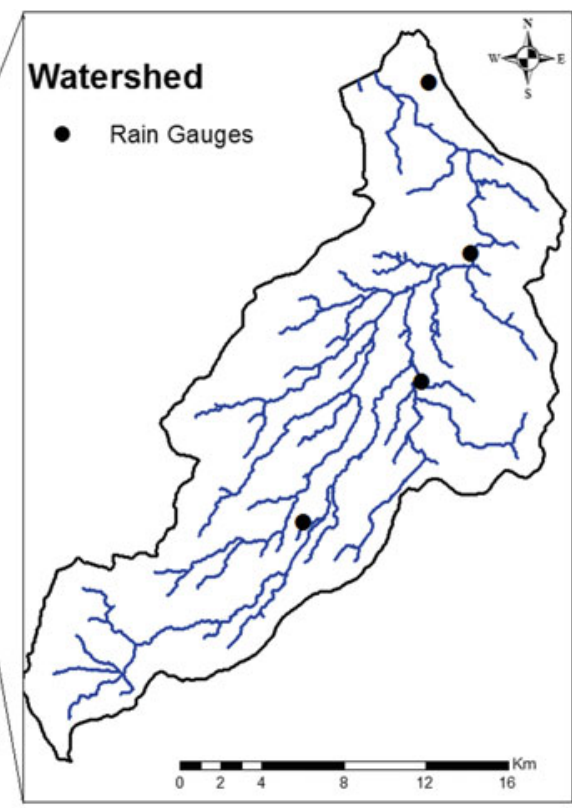

b)

Fig. 13.6 Map of Wadi Uday basin in Muscat, Oman (a), showing the locations of dams and rain gauges (b). Source data Ministry of Regional Municipalities and Water Resources, Oman (source Moya 2017)

\subsubsection{Hydrological Rainfall Runoff Inundation Model (RRI)}

The hydrological model utilized in this study is called the RRI, which is capable of simulating rainfall runoff and flood inundation simultaneously. The model deals with slopes and river channels separately, although they are both positioned in the same grid cells. In the model, the channel is discretized as a single line vector of the overlying slope grid cells (Sayama 2013, 2015). The channel represents an extra flow path between grid cells overlying the actual river course. Lateral flows are simulated on the cells on a 2D basis, and slope grid cells on the river channel have two water depths: one allocated for the channel and another for the slope.

Channel flow in the RRI model is calculated with the 1D diffusive wave model. The RRI model also simulates lateral subsurface flow, vertical infiltration flow and surface flow. This study focused on the case where there was no lateral saturated hydraulic conductivity to consider saturated subsurface and saturation excess overland flow. A particularity of the RRI model is that it can simulate both surface and subsurface flow with the same algorithm (Sayama 2013, 2015). 
The RRI model can also be used to simulate several mitigation measures, such as dams, diversion channels and channel improvements. To assess the current mitigation measures more accurately in arid and semiarid basins, this study also attempted, unsuccessfully, to change the dam subroutine embedded in the model to allow it to simulate dams with different discharge rates (as opposed to the normal RRI function, which sets discharge at a fixed rate and includes circular storage reservoirs). It is worth mentioning that the RRI model was efficiently applied in flash flood simulations in Oman (Abdel-Fattah et al. 2016, 2018).

\subsubsection{Governing Equations}

The model used to calculate lateral flows on slope grid cells is called the "storage cell-based inundation model" (Hunter et al. 2007) and is based on Eq. (13.2), describing mass balance, and Eq. (13.3), describing the momentum equation. These equations can be expressed as follows:

$$
\begin{gathered}
\frac{\partial h}{\partial t}+\frac{\partial q_{x}}{\partial x}+\frac{\partial q_{y}}{\partial y}=r \\
\frac{\partial q_{x}}{\partial t}+\frac{\partial u q_{x}}{\partial x}+\frac{\partial v q_{y}}{\partial y}=-g h \frac{\partial H}{\partial x}-\frac{\partial \tau_{x}}{\partial p_{w}}
\end{gathered}
$$

where $\mathrm{h}$ is the height of water of the surface, $q_{x}$ and $q_{y}$ are the unit width discharges in the $x$ and $y$ directions, $u$ and $v$ are the flow velocities in the $x$ and $y$ directions, $r$ is the rainfall intensity, $H$ is the height of water from the datum, $p_{w}$ is the density of water, $g$ is the gravitational acceleration, and $\tau_{x}$ and $\tau_{y}$ are the shear stresses in the $x$ and $y$ directions. These equations are then calculated using Manning's equation (Sayama 2013, 2015), after which the following equations are derived.

$$
\begin{aligned}
& q_{x}=-\frac{1}{n} h^{5 / 3} \sqrt{\left|\frac{\partial H}{\partial x}\right| \operatorname{sgn}\left(\frac{\partial H}{\partial x}\right)} \\
& q_{y}=-\frac{1}{n} h^{5 / 3} \sqrt{\left|\frac{\partial H}{\partial y}\right| \operatorname{sgn}\left(\frac{\partial H}{\partial y}\right)}
\end{aligned}
$$




\subsection{Model Calibration and Validation in Arid and Semiarid Regions}

\subsubsection{Calibration (Gonu 2007) and Parameter Setting}

Calibration was performed by comparing the discharge results from the RRI simulation to the actual measured discharge for the June 2007 Gonu Cyclone. The model was calibrated for 3 cases: case A for only overland flow, case B for vertical infiltration and case C for saturated subsurface (Sayama 2013, 2015). Due to the topographical particularities of the selected arid and semiarid basins, this study focused on case C. To perform the calibration, first, various parameters were adjusted until the simulated and measured discharge curves resembled each other, as shown in Fig. 13.7. The effect of each parameter as well as the values that were finally selected for the arid and semiarid basins are listed in Table 13.5.

Here, the suction at the vertical wetting front, $S_{f}$, is inactive, and the vertical saturated hydraulic conductivity, $k_{v}$, is zero, therefore, these parameters were omitted from the table.

Both daily and hourly calibrations were performed, and one large difference between these calibrations was the gap between the peak discharges of the measured and simulated values before calibration; this gap was much steeper in the hourly case. This was reflected in the values of the parameters, particularly the values for the roughness of the river and slope, which were significantly lower for the hourly calibration case than for the daily case. The final calibration result is shown in Fig. 13.8. The formulas that were used to assess the accuracy of these results are listed below:

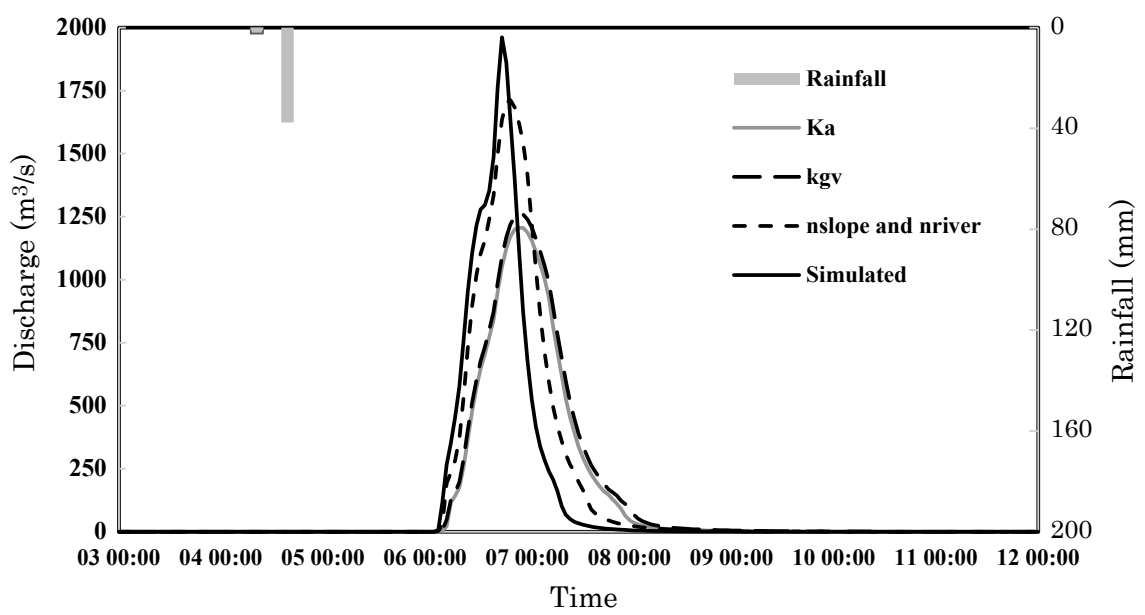

Fig. 13.7 Different calibration attempts together with the final simulated curve; the legend shows which parameter was changed for each line to increase or decrease the peak discharge 
Table 13.5 Value and effect of each parameter after calibration

\begin{tabular}{l|l|l}
\hline Parameter & Value & Effect \\
\hline $\begin{array}{l}n_{\text {river }}\left(m^{-1 / 3} s\right) \\
\text { (Roughness of river) }\end{array}$ & 0.02 & Considerable decrease in peak discharge \\
\hline $\begin{array}{l}n_{\text {slope }}\left(m^{-1 / 3} s\right) \\
\text { (Roughness of slope) }\end{array}$ & 0.05 & Decrease in peak discharge \\
\hline $\mathrm{d}(\mathrm{m})($ Soil depth $)$ & 0.7 & Slight decrease in peak discharge \\
\hline$\varphi($ Porosity $)$ & 0.3 & Slight decrease in peak discharge \\
\hline $\begin{array}{l}\mathrm{k}\left(m s^{-1}\right) \\
\text { (Lat. sat. hydr. conduc. })\end{array}$ & 0 & Low discharge peak \\
\hline$k_{g v}$ & $2 \mathrm{x}$ & Considerable overall decrease of discharge curve \\
(Groundwater hydr. conduc.) & \multicolumn{2}{|l}{} \\
\hline River settings & $\begin{array}{l}C_{w}=6.5 \\
S_{w}=0.56 \\
C_{D}=0.22 \\
S_{D}=0.32\end{array}$ \\
\hline
\end{tabular}

Source Moya (2017)

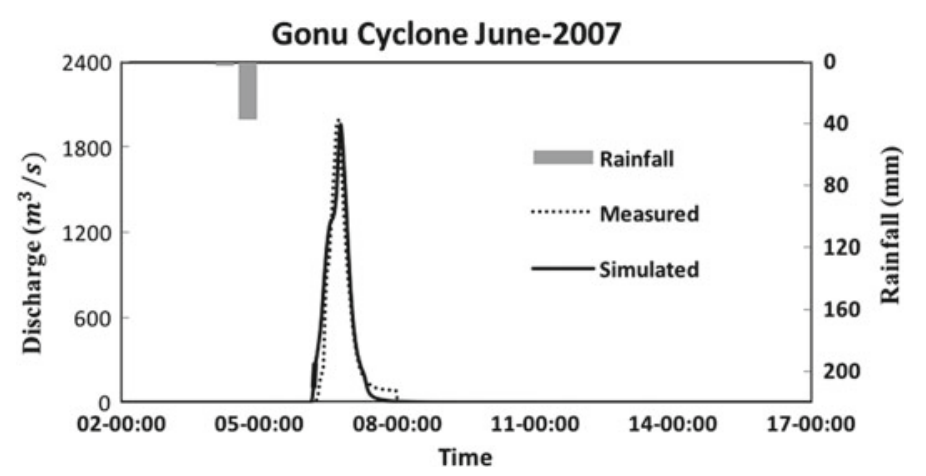

Fig. 13.8 Discharge peak from the measured data, as well as simulated values before and after calibration. Source Moya (2017)

$$
\begin{aligned}
& \mathrm{PBIAS}=\frac{\sum\left(Q_{\text {meas }}-Q_{\text {sim. }}\right)}{\sum Q_{\text {meas }}} * 100 \\
& \mathrm{NSE}=1-\frac{\sum\left(Q_{\text {meas }}-Q_{\text {sim. }}\right)^{2}}{\sum\left(Q_{\text {meas }}-Q_{\text {sim. }}^{\text {mean }}\right)^{2}}
\end{aligned}
$$

where $Q_{\text {sim. }}$ stands for the simulated discharge and $Q_{\text {meas }}$ is the measured discharge. The peak bias for the Gonu Cyclone event at Wadi Uday was calculated to be approximately 6\%, and the Nash-Sutcliffe model efficiency coefficient was approximately 0.98 . The width and depth of the channel were determined by 
comparing the simulated values with real values obtained from Google Maps. The channel in Wadi Uday was found to be rather deep and quite wide, especially in the upstream part, whereas the Sume channel in Brazil tended to be very flat and narrow. The flood depth level that was measured downstream was also used to prove that the calibration results here were valid. In the Sume Basin, due to a lack of measured discharge data, the results were not calibrated or validated.

\subsubsection{Validation (2006 December Floods)}

The December 2006 floods were selected to validate the calibration, following a similar procedure as mentioned in the beginning of this chapter, as shown in Fig. 13.9 in the appendix. The PBIAS used for the validation was estimated to be approximately $28 \%$. This exemplifies the reliability of the obtained parameters.

\subsection{Comparison of Flash Flood Mitigation Scenarios}

\subsubsection{Proposed Mitigation Scenarios}

Below are the main mitigation scenarios that were proposed, mainly for the distributed and concentrated structures in both the Wadi Uday basin and Sume Basin (Moya et al. 2017). The main point behind how the reservoir volumes were selected is that the total volume of all the reservoirs summed together always remained the same. The reservoir storage volume was chosen according to the topography of the

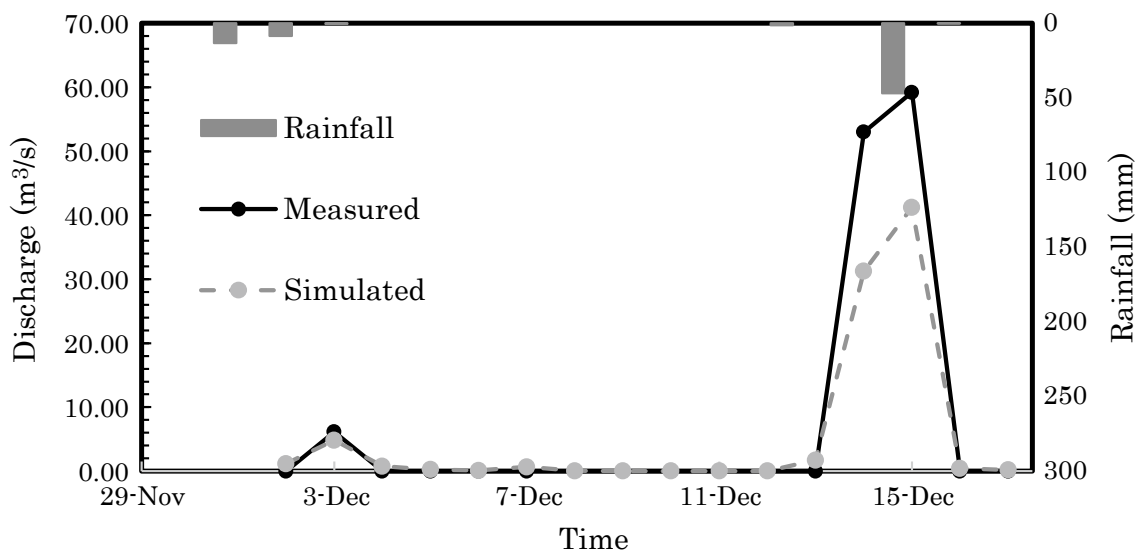

Fig. 13.9 Discharge peak curve of the December 2006 floods obtained after using the calibrated parameters from 2007 Gonu cyclone calibration 
basin. In Fig. 13.10, the concentrated dams that were proposed for each case study are shown, and their specifications are described in Tables 13.6 and 13.7. The distributed dams and information on the Sume Basin are displayed in Fig. 13.11 and Table 13.8.

\subsubsection{Impact of Mitigation Measures}

The main five scenarios compared were the scenario without mitigation measures, with 1 dam, concentrated dams, distributed dams, and channel improvement. In Fig. 13.12, the hydrograph of the Gonu Cyclone event in 2007 shows the efficiency of concentrated versus distributed mitigation structures based on daily data that were measured at a point downstream. In Fig. 13.13, the different water levels at the same point downstream are shown to illustrate how the various mitigation measures applied managed to decrease the maximum flood depth. The distribution maps were visualized for the flow discharge (Fig. 13.14) and flow depth with distributed and concentrated dams at Wadi Uday (Figs. 13.15 and 13.16). Both distributed and concentrated dams seemed to be more efficient in the Wadi Uday basin in terms of lowering both the discharge and flood depth, which could be attributed to the geomorphologic differences between the two channels. The main conclusion that can be drawn from these pictures is that distributed dams may be more effective in reducing flood depths and peak discharges. This could be because distributed dams can stop water at different time sets compared to the concentrated dam strategy, which might hold the flood water at a single point in time.

Similarly, the flood depth and discharge values as well as maps showing the distributions of these data based on measurements made at a downstream point were also performed in the Sume Basin. Figures 13.17 and 13.18 exhibit the hydrographs of the flow discharge and flow depth, respectively. The distribution
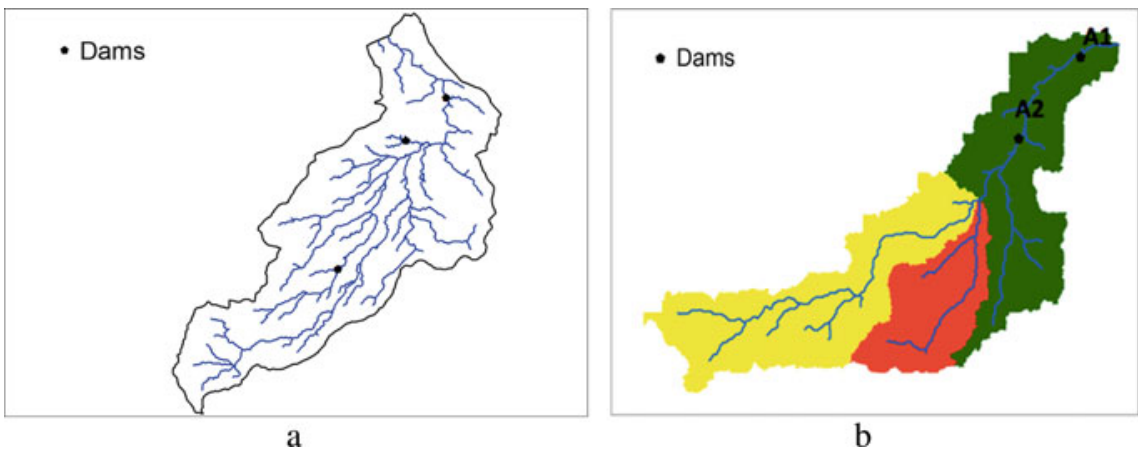

Fig. 13.10 Location of concentrated dams in the Wadi Uday basin (a) and Sume Basin (b). Source Moya (2017) 
Table 13.6 Information on concentrated dams in the Wadi Uday basin

\begin{tabular}{l|l|l|l|l|l}
\hline $\begin{array}{l}\text { Dam } \\
\text { ID }\end{array}$ & Dam name & $\begin{array}{l}\text { Dam } \\
\text { height } \\
(\mathrm{m})\end{array}$ & $\begin{array}{l}\text { Dam } \\
\text { coordinates }\end{array}$ & Dam type & $\begin{array}{l}\text { Reservoir storage } \\
\text { volume }\left(10^{6} \mathrm{~m}^{3}\right)\end{array}$ \\
\hline B15 & $\begin{array}{l}\text { Al Amerat } \\
\text { Heights }\end{array}$ & 22 & $\begin{array}{l}\text { Lat: } 23.54^{\circ} \\
\text { Long: } \\
58.49^{\circ}\end{array}$ & Embankment & 48 \\
\hline G2 & $\begin{array}{l}\text { Wadi Uday } \\
\text { Gorge }\end{array}$ & 45 & $\begin{array}{l}\text { Lat: } 23.58^{\circ} \\
\text { Long: } \\
58.52^{\circ}\end{array}$ & Embankment & 22 \\
\hline B4.1.2 & $\begin{array}{l}\text { Madinat Al } \\
\text { Nahdah S }\end{array}$ & 20 & $\begin{array}{l}\text { Lat: } 23.44^{\circ} \\
\text { Long: } \\
58.43^{\circ}\end{array}$ & Embankment & 19 \\
\hline
\end{tabular}

Source data Ministry of Regional Municipalities and Water Resources, Oman

Table 13.7 Information on concentrated dams in the Sume basin

\begin{tabular}{l|l}
\hline Dam ID & Storage volume $\left(10^{6} \mathrm{~m}^{3}\right)$ \\
\hline A1 & 35 \\
\hline A2 & 10 \\
\hline
\end{tabular}

Fig. 13.11 Location of distributed dams in the Sume basin. Reprinted (modified) from Moya et al. (2017) copyright 2021

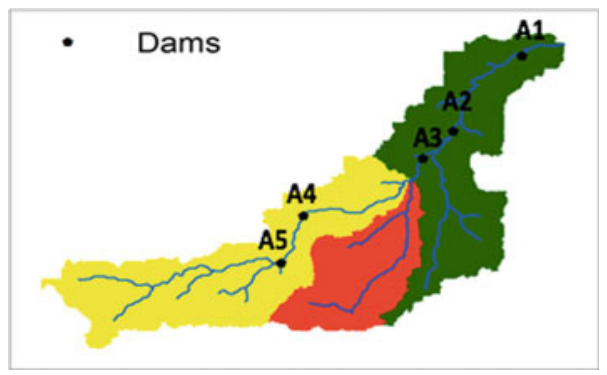

Table 13.8 Information on distributed dams in the Sume basin

\begin{tabular}{l|c}
\hline Dam ID & Storage volume $\left(10^{6} \mathrm{~m}^{3}\right)$ \\
\hline A1 & 25 \\
\hline A2 & 5 \\
\hline A3 & 5 \\
\hline A4 & 5 \\
\hline A5 & 5 \\
\hline
\end{tabular}

Source Ministry of Regional Municipalities and Water Resources, Oman

maps of discharge (Fig. 13.19) and flow depth with concentrated and distributed dams are also visualized (Figs. 13.20 and 13.21). 


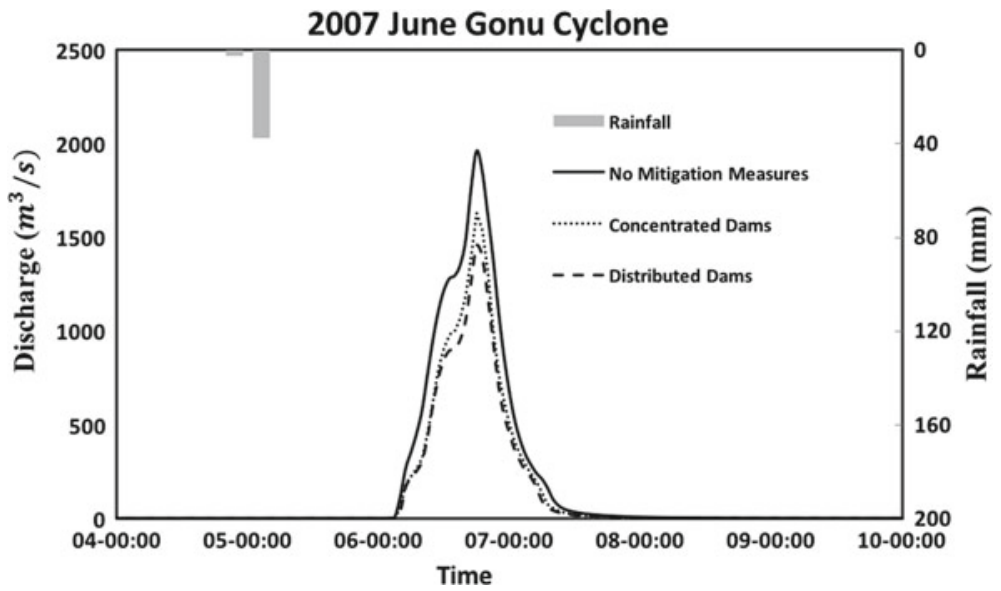

Fig. 13.12 Hydrograph showing the discharge peak in Wadi Uday considering various mitigation scenarios

Flood Water Level

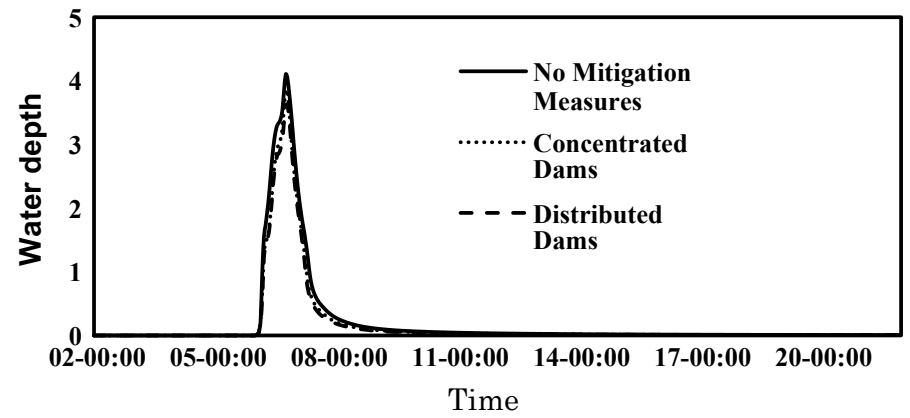

Fig. 13.13 Flood depth during the Gonu Cyclone in Wadi Uday measured at a point downstream
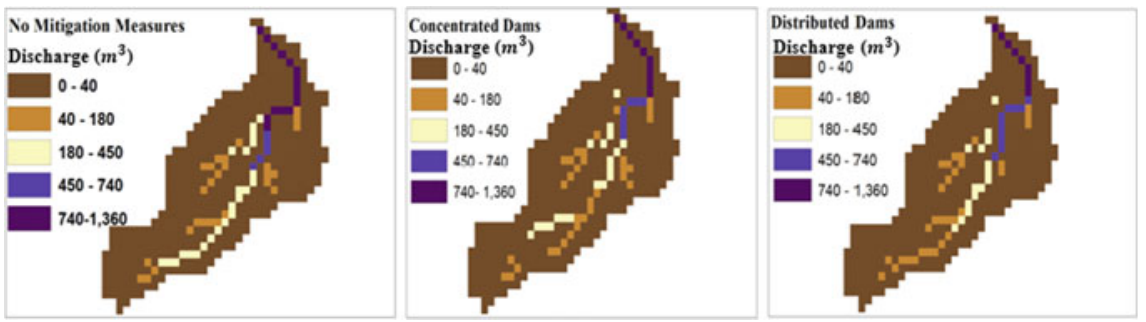

Fig. 13.14 Discharge maps of Wadi Uday for the 100-year rainfall return period under different mitigation scenarios 

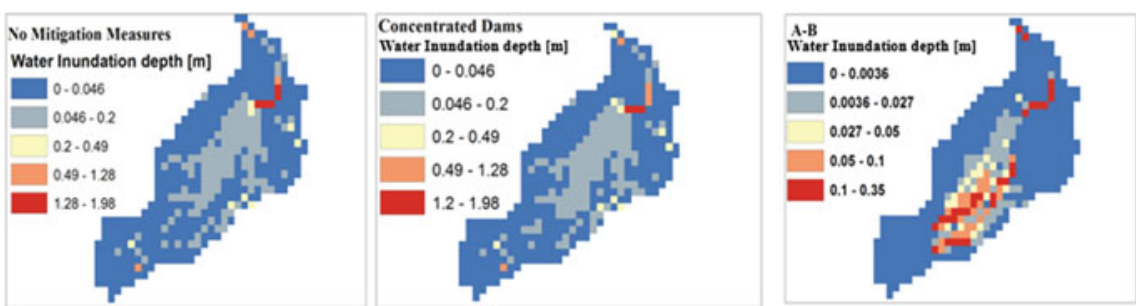

Fig. 13.15 Flood depths with concentrated dams; A-B represents the difference between the flood depths under the situation in which mitigation measures are taken and the situation in which mitigation measures are taken in Wadi Uday for the 100-rainfall return period
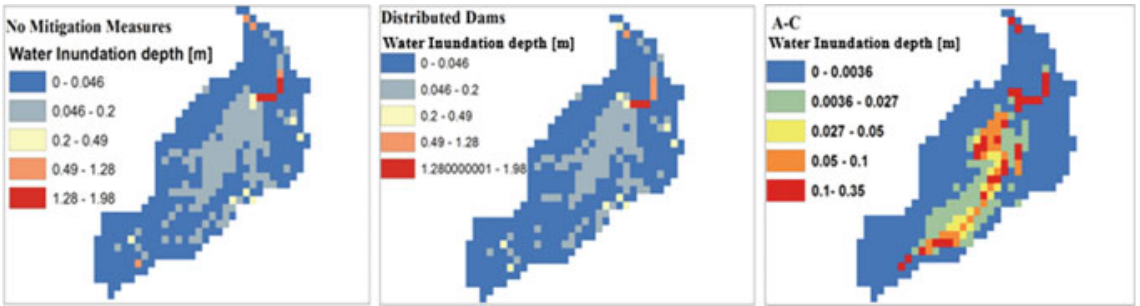

Fig. 13.16 Flood depths with distributed dams; A-C represents the difference between the flood depths under the situation in which mitigation measures are taken and the situation in which no mitigation measures are taken in Wadi Uday for the 100-year rainfall return period

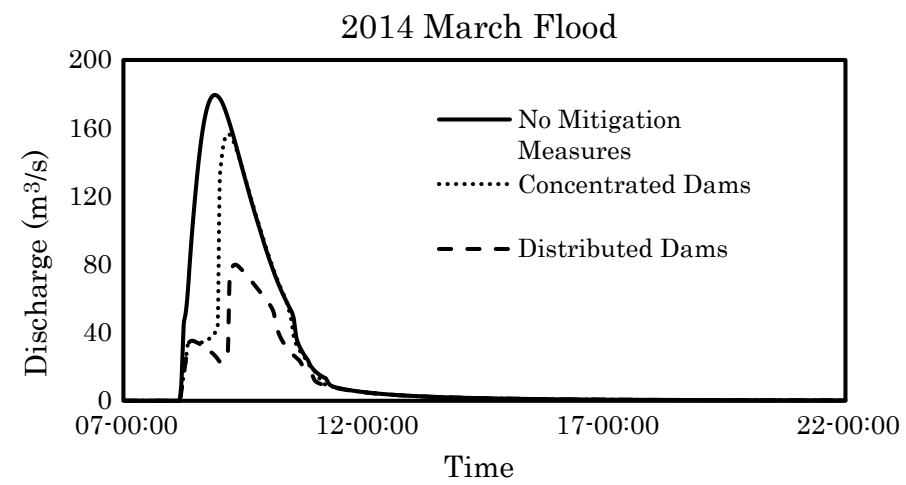

Fig. 13.17 Hydrograph of discharge peaks in Sume basin considering various mitigation scenarios 
Fig. 13.18 Flood depth during the Gonu Cyclone in the Sume basin measured at a point downstream
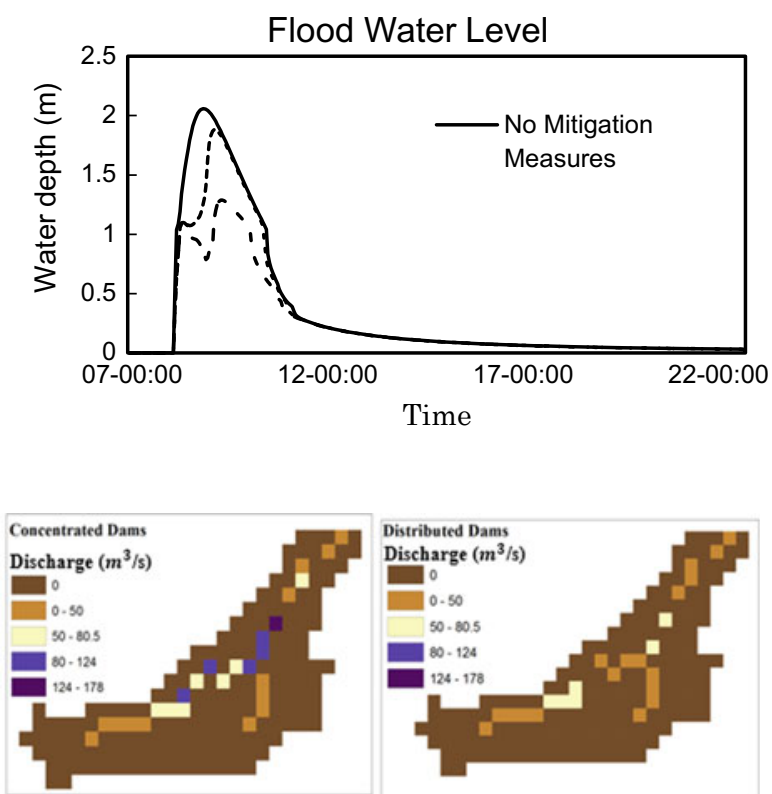

Fig. 13.19 Discharge maps in the Sume basin under different mitigation scenarios for the 100 -year rainfall return period

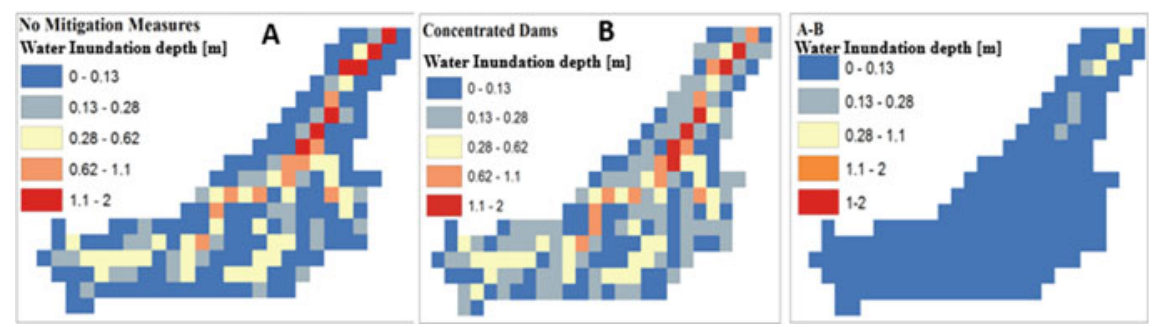

Fig. 13.20 Flood depths with concentrated dams; A-B represents the difference between the flood depths under the situation in which mitigation measures are taken and the situation in which no mitigation measures are taken in the Sume Basin based on the March 2014 flood event

\subsection{Flood Index}

The rainfall return period was calculated considering June 2007 Gonu Cyclone in Oman, and the March 1985 flood event in the Northeastern Region of Brazil. The rainfall return period was calculated using the following equation: 


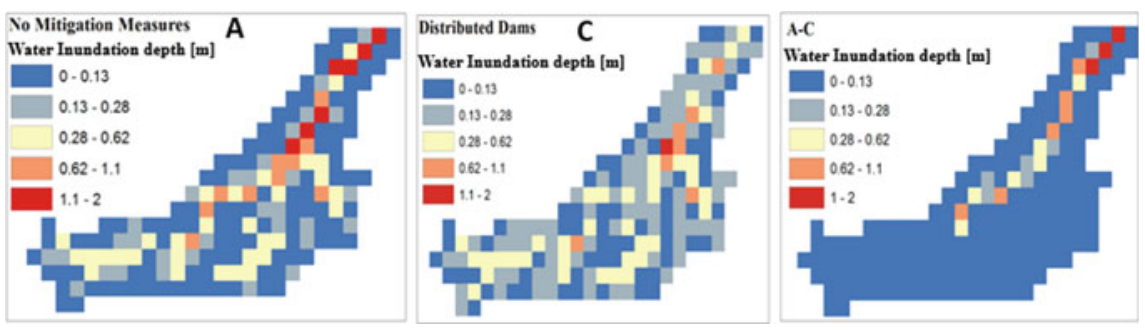

Fig. 13.21 Flood depths with distributed dams; A-C represents the difference between the flood depths under the situation in which mitigation measures are taken and the situation in which no mitigation measures are taken in the Sume Basin based on the March 2014 flood event

$$
\begin{gathered}
F_{a}=\frac{100(2 n-1)}{2 y} \\
\mathrm{FFI}=\frac{\sum_{i=1}^{N} I_{D}}{N}
\end{gathered}
$$

where $F_{a}$ is the probability of occurrence, $\mathrm{n}$ is the total number of years and $y$ is the total number of events. Using this rainfall return period, the flood index was estimated in the Sume Basin and in the Wadi Uday basin, as shown in Fig. 13.22. To calculate this flood index, Eq. 13.6 was used, where $I_{D}$ is the average inundation depth and $N$ is the total number of cells. The difference in the span of the return period graphs is due to the lack of available data for the Sume Basin in Brazil.

\subsection{Conclusions and Recommendations}

As shown in the previous section, concentrated dams did not reduce the inundation water level or total area as much as distributed dams did, and by observing the flood index, channel improvements were $20 \%$ more efficient in reducing the inundation depth of flash floods than the construction of dams. Furthermore, concentrated dams were much more efficient in arid basins than in semiarid basins. Concentrated dams seem to be less efficient in semiarid Brazil because of the flat terrain and localized rain. One common point among both basins, however, is that in both cases, channel improvements were always effective; this is mainly attributed to the accumulation of sedimentation in the channels and embankments, which can make the rivers more prone to flash floods.

The RRI model was used because of its ability to simulate results, including mitigation measures, within a very short time span. Both data input and output visualization can be performed very quickly using this model, and the results can be easily compared and validated by utilizing results from other hydrological models. 


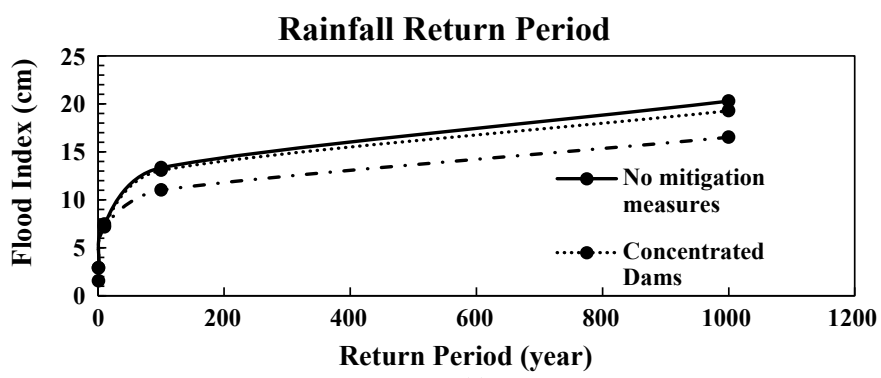

(a)

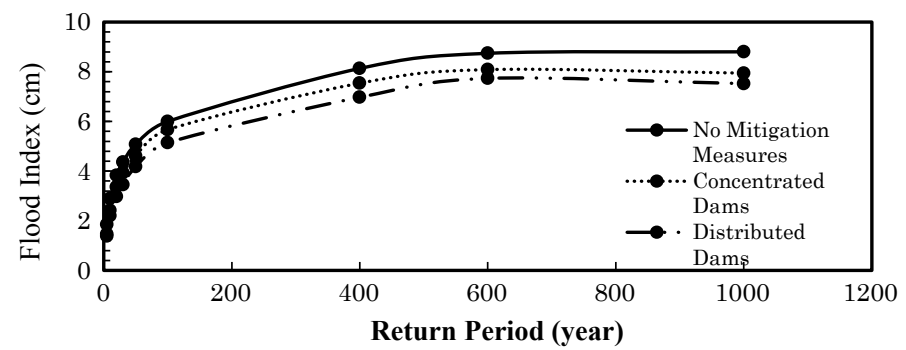

(b)

Fig. 13.22 Flood index curves plotted according to the rainfall return period for a Sume Basin, Brazil, and b Wadi Uday, Oman

The model was found to be suitable for simulations in arid and semiarid basins, as it provided accurate results after being calibrated and validated.

Despite the slight decrease in efficiency from a flood mitigation perspective, concentrated dams present other advantages. From an economic standpoint, they are much more affordable to construct since they centralize the necessary infrastructure, as seen in the construction of saddle dams, diversion channels and land survey costs for dams. Concentrated dams are also more efficient for groundwater recharge and are less harmful to the environment since concentrated dams require fewer construction materials. Additionally, concentrated dams are more easily accessible and maintained. Nevertheless, distributed dams also have advantages such as fostering local development in the local regions and providing more upstream protection from flash floods.

Overall, there seems to be a lack of academic papers that thoroughly compare arid and semiarid regions, especially from the perspective of hydrology and vulnerability to flash floods. Indeed, this might be because reliable data for flash floods in arid and semiarid basins are lacking; deeper investigation and research in disaster prevention in these regions only started in approximately 1980. One key difference this study found between semiarid Brazil and arid Oman is that the way each of these regions tackles flood problems is quite different. In northeastern Brazil, flash floods are mostly mitigated at a local level, with the subbasin being the main point of focus. In Oman, on the other hand, there is more of an integrated mitigation 
strategy plan at a national level considering the entire basin. This study concluded that Oman's more unified mitigation strategy was more efficient in preventing flash floods, especially because it took into account the topography of each basin; in the Brazilian semiarid region, mitigation measures are often relegated to nonstructural measures such as land evacuation plans and flood-risk maps. The frequency of flash floods is lower in arid basins than in semiarid basins; however, the magnitudes of flash floods are higher in the former. In recent times, Oman has had an unprecedented string of flash floods due to cyclones and thunderstorms that have combined to cause very intense precipitation events. Despite the recentness of this phenomenon affecting Oman, the government has developed a successful plan based on distributed structural measures, as seen in the previously mentioned seven-dam project in Wadi Uday. Such policies can be a great lesson for semiarid Brazil, which lacks inclusive and comprehensive structural measures to address the flash flood phenomenon.

\section{References}

Abdel-Fattah M, Kantoush S, Sumi T (2015) Integrated management of flash flood in wadi system of Egypt: disaster prevention and water harvesting

Abdel-Fattah M, Kantoush S, Saber M, Sumi T (2016) Hydrological modelling of flash flood at wadi samail, Oman

Abdel-Fattah M, Saber M, Kantoush SA, Khalil MF, Sumi T, Sefelnasr AM (2017) A hydrological and geomorphometric approach to understanding the generation of wadi flash floods. Water 9 (7):553. https://doi.org/10.3390/w9070553

Abdel-Fattah M, Kantoush SA, Saber M, Sumi T (2018) Rainfall-runoff modeling for extreme flash floods in wadi samail, Oman. J Jpn Soc Civ Eng Ser B1 (Hydraul Eng) 74(5):I_691I_696. https://doi.org/10.2208/jscejhe.74.5_I_691

Abdel-Fattah M, Kantoush S, Saber M, Sumi T (2021) Evaluation of structural measures for flash flood mitigation in wadi abadi region of Egypt. J Hydrol Eng. https://doi.org/10.1061/(ASCE) HE.1943-5584.0002034

Abdrabo KI, Kantoush SA, Saber M, Sumi T, Habiba OM, Elleithy D, Elboshy B (2020) Integrated methodology for urban flood risk mapping at the microscale in ungauged regions: a case study of Hurghada, Egypt. Remote Sens 12(21):3548. https://doi.org/10.3390/rs12213548

Al Barwani AS (2016) Omani experience in flash floods, disaster risk reduction and water harvesting. In: Proceedings of the second international symposium on flash floods in wadi systems: disaster risk reduction and water harvesting in the Arab region, pp 19-24

Alcantara HM, Cunha JEB, Galvao CO, Taveira IML (2013) Decisions on land conservation practices in a semi-arid region considering hydrological and social drivers. IAHS-AISH Publ 359:352-357

Al-Rawas GAA (2011) Flash flood modelling in Oman Wadis. Library and Archives Canada, Bibliothèque et Archives Canada, Ottawa

Al-Rawas GAA (2013) Urbanization impact on rainfall runoff modeling; an integration of remote sensing and GIS approach. In: Proceedings of the international conference on water resources and environment research

Anon (2000) The disparity between extreme rainfall events and rare floods- - with emphasis on the Semi-arid American West. Hydrol Process 13

Cadier E, Jose de Freitas B (1982) Bacia Representativa de Sumé: Primeira Estimativa Dos Recursos de Água 
Chimnonyerem UN (n.d.) Meeting the challenges of flood risk assessment in data poor developing countries, with particular reference to flood risk management in Lagos, Nigeria, p 375

Cutter SL, Munich Re Foundation Chair on Social Vulnerability, and Summer Academy on Social Vulnerability (eds) (2013) From social vulnerability to resilience: measuring progress toward disaster risk reduction outcomes of the 7th UNU-EHS summer academy of the Munich Re Foundation Chair on Social Vulnerability, 1-7 July 2012, Hohenkammer, Germany

Geber BDA, de Melo JSP, Giongo PR, Lira Júnior MdA, da Silva APN (2008) Relação Entre Condições Hídricas e o Crescimento Vegetal Da Cana-de-Açúcar No Município Itambé, Pernambuco. Revista Caatinga 21(5):171-77

Huang G, Shen Z (eds) (2019) Urban planning and water-related disaster management. Springer International Publishing, Cham

Huang J, Haipeng Yu, Guan X, Wang G, Guo R (2016) Accelerated dryland expansion under climate change. Nat Clim Chang 6(2):166-171. https://doi.org/10.1038/nclimate2837

Hunter NM, Bates PD, Horritt MS, Wilson MD (2007) Simple spatially-distributed models for predicting flood inundation: a review. Geomorphology 90(3-4):208-225. https://doi.org/10. 1016/j.geomorph.2006.10.021

Jha AK, Bloch R, Lamond J (2012) Cities and flooding: a guide to integrated urban flood risk management for the 21 st century. The World Bank

Knighton D (1984) Fluvial forms and processes. Edward Arnold Inc., New York

Kwarteng AY, Dorvlo AS, Vijaya Kumar GT (2009) Analysis of a 27-Year rainfall data (19772003) in the Sultanate of Oman. Int J Climatol 29(4):605-617. https://doi.org/10.1002/joc.1727

Lin X (1999) Flash floods in arid and semi-arid zones. Technical Documents in Hydrology

Lindoso D, Eiró F, Bursztyn M, Rodrigues-Filho S, Nasuti S (2018) Harvesting water for living with drought: insights from the Brazilian human coexistence with semi-aridity approach towards achieving the sustainable development goals. Sustainability 10(3):622. https://doi.org/ $10.3390 / \mathrm{su} 10030622$

Lindoso DP, Pereira Filho SR (n.d.) Vulnerabilidade e adaptação da vida às secas, 519

Malveira VTC, de Araújo JC, Güntner A (2012) Hydrological impact of a high-density reservoir network in semiarid Northeastern Brazil. J Hydrol Eng 17(1):109-117. https://doi.org/10.1061/ (ASCE)HE.1943-5584.0000404

Marengo JA, Nobre CA, Tomasella J, Oyama MD, de Oliveira GS, de Oliveira R, Camargo H, Alves LM, Foster Brown I (2008) The drought of amazonia in 2005. J Clim 21(3):495-516. https://doi.org/10.1175/2007JCLI1600.1

Metzger A, Marra F, Smith JA, Morin E (2020) Flood frequency estimation and uncertainty in arid/semi-arid regions. J Hydrol 590:125254. https://doi.org/10.1016/j.jhydrol.2020.125254

Ministry of Regional Municipalities and Water Resources (2009) Wadi Aday flood protection dams. 1. Oman.

Moya J, Kantoush SA, Abdel-Fattah M, Sumi T, Saber M (2017) A comparative study between flash floods in arid and semi-arid basins with respect to economic mitigation measures, pp 2122

Pathirana A, Denekew HB, Veerbeek W, Zevenbergen C, Banda AT (2014) Impact of urban growth-driven landuse change on microclimate and extreme precipitation-a sensitivity study. Atmos Res 138:59-72

Rogger M, Viglione A, Derx J, Bloeschl G (2014) Step changes in the flood frequency curve-quantifying effects of catchments storage thresholds. EGUGA 12100

Saber M, Abdrabo KI, Habiba OM, Kantosh SA, Sumi T (2020) Impacts of triple factors on flash flood vulnerability in Egypt: urban growth, extreme climate, and mismanagement. Geosciences 10(1):24

Saber M, Habib E (2016) Flash floods modelling for wadi system: challenges and trends. In: Landscape dynamics, soils and hydrological processes in varied climates. Springer, Berlin, pp 317-339

Saber M, Hamaguchi T, Kojiri T, Tanaka K (2010) Flash flooding simulation using hydrological modeling of wadi basins at Nile river based on satellite remote sensing data 
Saber M, Kantoush S, Abdel-Fattah M, Sumi T (2017) Assessing flash floods prone regions at wadi basins in Aswan, Egypt. 京都大学防災研究所年報. B= Disaster Prev Res Inst Annuals B 60(B):853-863

Saleh AS, Al-Hatrushi SM (n.d.) Torrential flood hazards assessment, management, and mitigation, in wadi aday, Muscat area, Sultanate of Oman. GIS RS Approach 17

Sayama T (2013) Rainfall-runoff-inundation (RRI) model ver. 1.4. 2. International Center for Water Hazard and Risk Management (ICHARM), Public Works Research Institute (PWRI)

Sayama T (2015) Rainfall-runoff-inundation (RRI) model manual, version 1.4. 2, International Center for Water Hazard and Risk Management (ICHARM), Public Works Research Institute (PWRI)

Silva JC, Heldwein AB, Martins FB, Trentin G, Grimm EL (2007) Análise de distribuição de chuva para Santa Maria, RS. Revista Brasileira de Engenharia Agrícola e Ambiental 11(1):6772. https://doi.org/10.1590/S1415-43662007000100009

Tanaka* K, Omar H, Tanaka S (2020) Changes in extreme rainfall in arid and semi-arid region projected by super high resolution AGCM. In: Fifth international conference on engineering geophysics (ICEG). Society of Exploration Geophysicists, Al Ain, UAE, pp 296-299

Wang D, Zhao H (2008) Estimation of phytoplankton responses to hurricane Gonu over the Arabian Sea based on ocean color data. Sensors 8(8):4878-4893. https://doi.org/10.3390/ s8084878

Wheater H, Sorooshian S, Sharma KD (2007) Hydrological modelling in arid and semi-arid areas. Cambridge University Press

Open Access This chapter is licensed under the terms of the Creative Commons Attribution 4.0 International License (http://creativecommons.org/licenses/by/4.0/), which permits use, sharing, adaptation, distribution and reproduction in any medium or format, as long as you give appropriate credit to the original author(s) and the source, provide a link to the Creative Commons license and indicate if changes were made.

The images or other third party material in this chapter are included in the chapter's Creative Commons license, unless indicated otherwise in a credit line to the material. If material is not included in the chapter's Creative Commons license and your intended use is not permitted by statutory regulation or exceeds the permitted use, you will need to obtain permission directly from the copyright holder.

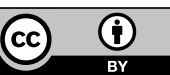

